\title{
EMERGING ISSUES IN THE INTERNATIONALIZATION OF CANADIAN HIGHER EDUCATION
}

\author{
EMMA SABZALLEVA
UNESCO INTERNATIONAL INSTITUTE FOR HIGHER EDUCATION
AND YORK UNIVERSITY
}

\section{Higher Education Internationalization at a Juncture}

In Canada, as in many other jurisdictions, the ongoing intensification of internationalization has become taken for granted, now woven into the everyday fabric of the higher education landscape. When planning for this special issue began in 2019 , preceded by the Shaping Sustainable Futures for Internationalization in Higher Education (SSFIHE) conference at the University of Toronto, it already felt like the world of higher education internationalization had for some time been moving into new realms. In scholarly circles in this pre-Covid era, debates over the current status and future of internationalization were raging. Was the end of higher education internationalization nigh? Or, as others argued, was the future bright, but perhaps a little different from what had come before? (see, e.g., Altbach \& de Wit, 2018; Knight \& de Wit, 2018; Mok, 2018; Proctor \& Rumbley, 2018).

Shifts external to higher education were forcing open this juncture, with some governments appearing to turn away from international affairs. For a field that finds its meaning in international connections, what was happening in other nations both near and far was highly relevant for Canada. As this discourse became translated into policies and actions, the future for higher education internationalization - once seemingly on an infinitely upwards trajectory-was called into question for perhaps the first time. In this context of rising nationalism, populism, and backlash to global interconnectedness, some suggested that this was "Canada's global moment" (Universities Canada, 2017).

Yet that moment was complex. For example, while the so-called "Trump bump" (Yerger \& Choudhary, 2019, p. 1200) led to huge increases in international applications to Canadian universities and colleges, those same institutions were also reeling from a politically motivated decision by Saudi Arabia to suddenly pull its large student population from Canadian campuses (Trilokekar et al., 2020). From a policy perspective, the end of the 2010s saw the federal government's International Education Strategy (2014-2022) reach its midway evaluation point in 2018 (Global Affairs Canada, 2019) as well as political change, with new provincial governments formed after elections in top international student destinations Ontario and Québec. In Ontario, the right-wing populist Ford administration made a series of cuts to higher education-totalling \$450m in 2019 alone-leading universities and colleges to be ever more reliant on international students to make up funding gaps (Paikin, 2019; Syed, 2019). Under the Coalition Avenir Québec government that has been in power since 2018, immigration has been reduced, which has negatively impacted a provincial immigration program that was previously open to international students graduating from Québec's universities and colleges (Shingler, 2019). The effect of political changes in these provinces may not have decreased the flow of international students, but they have affected how this group are perceived by universities and colleges and the likelihood that they can make longer-term economic and social contributions to Canada.

Taken together, developments in research, policy, and practice related to higher education internationalization were demonstrating new trends, adjustments to existing patterns as well as emergent gaps in our understanding of internationalization both in theory and in practice. By positioning that moment as a turning point for higher education internationalization, the SSFIHE conference created space to take stock of the ways in which internationalization has developed and what it might look like into the future. Three themes were identified as particularly relevant to informing these conver- 
sations: quality, reciprocity, and inclusivity as they relate to shaping sustainable futures for internationalization in higher education.

A particular focus for the stocktaking at SSFIHE was on Canadian higher education, although with 175 delegates from 20 countries converging in Toronto in the months before borders were shut down by Covid-19, the conference was wide open to contrasting perspectives and evidence from other settings that are relevant to the landscape in Canada. A common theme that emerged during the conference related to the need to deepen our understanding of the implications of present internationalization practices for the future. As a result, the objective of this special issue is to fill this gap through articles that engage with under-researched aspects of internationalization and examine higher education internationalization through alternative lenses and viewpoints.

This opening essay, written by one member of the five-person-strong conference organizing committee, first brings together some of the key features of higher education internationalization as it has developed in Canada. The article identifies some of the emerging issues for the future of internationalization which resonate in the Canadian context but also, as SSFIHE delegates found, extend well beyond Canada. These issues are discussed alongside an introduction to the articles in this collection. In so doing, the article sets out a new agenda for Canadian higher education internationalization research, policy, and practice. Whereas the discussions around higher education internationalization in this collection all began prior to 2020 , it is no longer possible to do research or make policy on internationalization without reference to Covid-19. In concluding, the effects of this global pandemic are considered as part of the new landscape in which we must now all contend.

\section{The Development of Higher Education Internationalization in Canada}

As a topic of scholarly research and debate, the internationalization of higher education has emerged as a major theme within the interdisciplinary field of higher education research. Early work in the 1980s and 1990s traced the contours of the issue, and research has grown since, in step with the phenomenon itself. Canada has produced several important scholars of internationalization, including one of the most eminent on the topic, Jane Knight, who was also one of three keynote speakers at the SSFIHE conference. Knight's definition of internationalization became widely accepted and used in the field (Knight, 2003), subsequently generating a range of alternatives and modifications.

Alongside the array of concepts, multiple critiques of internationalization have emerged, even from those who have sought to promote its use in research and practice. In acknowledging its centrality to contemporary higher education, Knight nevertheless notes that the term "has become a catch-all phrase used to describe anything and everything remotely linked to the global, intercultural or international dimensions of higher education" (Knight, 2014, p. 76).

Beyond the misuse of the concept, Kumari Beck has cogently argued that it is in fact the substance of internationalization that is being misappropriated. In this way, practices of internationalization such as international student recruitment may reproduce "the harmful influences of globalization and colonial legacies" (Beck, 2013, p. 55). Sharon Stein, a fellow critical scholar and convenor of the recently established Critical Internationalization Studies Network, has similarly emphasized the role that internationalization plays in reinforcing the dominant global imaginary of Western supremacy. In this imaginary, in which Canada is deeply implicated, "the West is understood to be at the top of a global hierarchy of humanity with the rest of the world trailing behind" (Stein \& de Andreotti, 2016, p. 226). For all its touted roles in building understanding and bridges between cultures and peoples, internationalization from this critical stance is outright exclusionary and racist-not without redemption, but in severe need of ethically grounded revision.

This aspect of internationalization comes to light because of the valuable contributions made by scholars in Canada and internationally, but often stands in contrast to the ways that higher education internationalization is discussed and implemented as an area of policy and practice. Indeed, the divergences that can be identified when studying internationalization from these different perspectives-and the lack of conversation between them despite their connectedness-was one of the driving forces behind the SSFIHE conference's ambition to bring together researchers, policy makers, and practitioners.

In terms of policy, the internationalization of higher 
education has gained the attention of governments in Canada and abroad. The Canadian federal government has commissioned several reports on the economic impact of international students, most recently reporting that they contribute over $\$ 20$ billion to Canada's GDP and support almost 170,000 jobs (Global Affairs Canada, 2017; Government of Canada, 2019). The first federal strategic plan for international education was published in 2014 and updated in 2019 (Global Affairs Canada, 2014; Government of Canada, 2019). The emphasis in both has been on growing international student enrolments and, to a lesser extent, increasing study abroad by Canadian students. While the economic benefits of international students are at the forefront of the current international education strategy, the longer-term aim to retain Canadian educated students as "ideal immigrants" has also become more overt in the federal policy discourse (Scott et al., 2015).

At the provincial level, some governments developed international education plans much earlier, such as in Alberta (2001) and Québec (2002), while others are more recent, such as British Columbia (2012) and Ontario (2018). Non-governmental organizations in Canada are also engaged in policy. These range from ad hoc groups such as the multi-sector Study Group on Global Education, which drew from academia, industry, and civil society to develop a set of policy recommendations for improved international engagement by students (Study Group on Global Education, 2017), to advocacy bodies such as Universities Canada and Colleges \& Institutes Canada, both of which have student mobility and international partnerships as core priorities. However, these policies struggle to go beyond the attraction of international students (and their tuition payments), while the Canadian dynamic of distinct provincial and federal roles in education complicates efforts to set Canada apart as a global leader for international higher education.

As an area of practice, Canadian higher education institutions are deeply engaged in internationalization. International student enrolment has grown dramatically on Canadian campuses, expanding by $226 \%$ between 2000 and 2014 and another 34\% between 2014 and 2017 (Canadian Bureau for International Education, 2018; Sá \& Sabzalieva, 2018). Canadian institutions have developed overseas branch campuses, such as those in India, United Arab Emirates, United Kingdom, and Qatar. They are developing joint and dual degree programs with institutions around the world, and even licensing aca- demic programs to partner organizations. Along with this growth, Canadian universities and colleges have institutionalized their global engagement by creating strategic plans and organizational structures aimed at managing the complexities of internationalization. Institutions have developed international offices offering a host of international related services, and often assign a senior institutional administrator to the portfolio.

\section{Setting a New Agenda for Canadian Higher Education Internationalization}

Higher education internationalization in Canada has thus developed at an ever-increasing pace with a particular emphasis across research, policy, and practice on the role of international students. Other aspects of internationalization such as international research collaborations and intercultural learning are also expanding but receive far less attention than internationalization in relation to students. From this base, the articles in this special issue can be contextualized and positioned in the ways they enable our understanding and critiques to move forward. The articles all have distinct approaches and focal points and taken together they support the advancement of a new agenda for Canadian higher education internationalization. This is achieved both in how internationalization is researched and in terms of the implications and possibilities the studies open for policy and practice.

Conceptually, this new agenda crosses multiple levels of analysis: the international, the national/federal, the provincial, higher education institutions (universities and colleges), and the individuals within higher education. The articles look both historically and to the present to inform their discussion and analysis of what may lie ahead for internationalization. Topics discussed in the articles range from international collaborations to internationalization strategies, and from the funding of international higher education to international students' mental health. While these articles are grounded in Canadian experiences, there are lessons to be drawn and ideas that can be further explored in other contexts such as Anglo-dominant societies, federal states, and elsewhere.

Whereas most of the articles centre Canada in their discussions of internationalization (even when they critique this very centring), Schiedeck's contribution is notable for its examination of Canada from the perspec- 
tive of Brazil. Schiedeck also picks up on an emerging and under-studied element of internationalization in the Canadian context, namely how this is occurring in the vocational education and training (VET) sector as offered by colleges (in Canada) and Federal Institutes (in Brazil). After providing a useful overview of the position of VET as part of the broader globalization of education and helpful contextual data on the Brazilian VET system, Schiedeck explores cooperation between Canada and Brazil at institutional level. Specifically, the article examines the A Thousand Women project that has supported women's professional development, and the later emergence of the Science Without Borders mobility program.

These cooperation projects enable a discussion of the array of actors involved. The Secretariat of Professional and Technological Education of the Ministry of Education in Brazil appears to have played a decisive role in driving cooperation forward as well as supporting institutions to implement lessons learned. Schiedeck also points to the role of advocacy bodies such as Colleges and Institutes Canada and the World Federation of Colleges and Polytechnics, which is headquartered in Ottawa, as important actors. Whereas the narrative of cooperation between Canada and Brazil is commonly framed in terms of a North-South unequal relationship, Schiedeck's article aims to move beyond this by showing how these forms of internationalization have enabled otherness to be recognized and used to motivate innovation and effective collaboration.

Within Canada's national borders, the complication of the country's federal structure is addressed in McCartney's article on policy talk, that is, the statements made by federal parliamentarians in recorded sessions of the House of Commons pertaining to how they construct international students. Remarkably, McCartney finds considerable convergence in this policy talk even over a 35year period through the interventions made by multiple Members of Parliament (MPs) across the political spectrum. Policy talk has congregated around two themesthe quality of Canadian higher education and the value of international students for Canada. These themes, McCartney argues, are so widespread as to have become taken for granted. In reference to the first theme, these taken for granted assumptions convey a positive view of the high quality of Canadian higher education. Following from this perspective, it is assumed that international students are naturally attracted to Canadian institutions because of their quality, that these institutions could be selective and choose only the brightest and best international students, and that those international students who later return home would by implication be equipped to support the development of their countries.

These imperialist and exclusionary narratives are mirrored in the second theme McCartney identifies, which puts Canada at the heart of the international education effort. MPs discuss the value of international students to Canada: their economic benefit, their ability to make Canadian campuses more cosmopolitan, and, in recent years, their value as immigrants to the country. Canada has little to learn from international students in this worldview. By calling out the role of politicians in shaping the internationalization discourse, McCartney's message is powerfully conveyed through this analysis of parliamentary debate. If higher education internationalization-in particular, international student recruitmentis to be sustainable, then these assumptions have to not only be questioned, but fundamentally altered. There needs to be a shift from a unilinear arrangement advantageous only to Canada to a more holistic framework in which knowledge and benefits are shared.

The need to frame internationalization differently is also integral to Buckner et al.'s review of 32 internationalization strategies published in English by universities and colleges across Canada. Their study instills importance to these "discursive artifacts" (p. 23) in the ways that they present an official approach to internationalization and subsequently support resource and priority allocation within the institution. The authors' content analysis finds very little differentiation in how internationalization is understood, regardless of institutional type (university or college) and geographical location. As other articles in this collection point to, the main focus is on students-both recruiting international students and supporting the outbound mobility of domestic students. Another common priority was on developing partnerships. The only real differences seem to be some greater emphasis on research in universities strategies compared to their college counterparts, and some placebased references to local challenges and opportunities.

Having shown the distinction between symbolic commitments (e.g., educating for a diverse world) and strategic justifications for internationalization (e.g., supporting research productivity), the authors find that the sampled internationalization policies combine these. As 
such, the symbolic and the strategic rationales are not distinct or competing but are typically brought together, thus imbuing "the same activities with multiple meanings that may resonate with diverse stakeholders" (p. 30). A significant finding of the study is the absence of what the authors classify as anti-oppressive values. Such values encompass empathy, social justice, reciprocity, and equity; ideals that might be expected to inform institutional attempts to indigenize and decolonize Canadian higher education as has apparently been the mantra of the sector in recent years. The lack of symbolic or strategic commitments to anti-oppressive aims in these internationalization strategies speaks volumes, both to the emptiness of the many words written over the need to change higher education, as well as to the ongoing disconnect between internationalization and the broader functions and purpose of higher education.

The relationship between discourse and policy is further taken up in King's analysis of the impact of government policy on the rationales for internationalization across 16 universities in British Columbia and Ontario. It draws on both document analysis and interviews with high level administrators with an internationalization portfolio at each of the case study universities. Where Buckner et al. focus on the content that is both present and absent in these strategies, King turns our attention to the ideas and the people that make up the paradigms and policy rationales for internationalization strategies. This is taking place in a context where internationalization is increasingly institutionalized, for instance becoming a permanent office of the university's central functions and thereby also benefiting from access to resources. The discursive institutionalist framework used in the paper shines a light on issues of power, both in the discursive content-the ways that actors use ideas to convince others to get on board with actions and viewpoints-and the conceptualization of the policy-making discursive community, which King describes as the actors that are involved in the discussion and the types of discourse that take place.

The article finds a subtle but noticeable shift away from the competitiveness paradigm that has become well established as the dominant rationale for internationalization. In its place, ideas about social responsibility-the university's place, purpose, and community-are becoming more important. This shift is more evident at globally and nationally oriented universities; those with more of a regional orientation continue to be embedded in a market discourse. Another important finding of the article is the minimal influence of either government or external actors to the process of formulating institutional internationalization policies. King puts this down to the decentralized, delegated and deconcentrated nature of university governance in Canada: that is, a combination of no federal remit for education, weak provincial leadership, diffused organizational authority, and high levels of institutional autonomy. Government influence where it exists comes from immigration and funding policy, not education or internationalization. Looking ahead, King suggests how a national or provincial ideational policy space could emerge, but also sees the possibility that such a space may never materialize.

One province that has taken action is the Ontario government, which launched the Trillium Scholarship in 2010 to provide funding to 75 international students per year at Ontario's universities and colleges. This is taken up in El Masri's article as an emblem of a shift in the international student discourse in the province. Using the discourse coalition framework, El Masri identifies three key storylines that had emerged during the second half of the twentieth century as Canadian higher education gradually opened up internationally. These discourses of economy, risks, and gateways were advocated for by different coalitions-not necessarily cohesive sets of actors consciously working together but grouped by their alignment to a set of ideas represented by these discourses. The economy storyline, which emphasizes the financial gains of internationalization, is inherent in policy discourse around the world; less visible are the storylines of risks (one the one hand, protecting international students from fraud and on the other, protecting Canada from those seeking to gain illegal access through international student routes) and gateways (in which international education opens access to the world and to the exchange of knowledge and global citizenship).

The 2010 announcement of the new Trillium scholarship scheme came as a surprise to many, as the primary interviews El Masri conducted demonstrate. This element of unexpectedness forced open the three previous storylines, shifting their (re)telling of international education narratives and eventually leading to coalescence around two new storylines. The first is supportive of the new financial investment, finding this symbolic of the importance of (literally and metaphorically) investing 
in international students in Ontario. The second smaller but no less vocal storyline is the "Ontario first" narrative in which the province's needs-funding domestic students and bringing the benefits of internationalization to Ontario-are foremost. El Masri's innovative use of the discourse coalition framework provides a fresh theoretical lens that supports a more nuanced analysis of the multiple actors involved in internationalization, which is then complicated further by Canada's federal structure. The concern raised by El Masri that the Ontario first discourse could "undermine the core values of internationalization" (p. 15) underlines the importance of analysing the confluence of politics at all levels (provincial, national, regional, global) in how higher education internationalization is shaped.

As these articles also point to, critiques of higher education internationalization have commonly focused on the ways in which it is deployed strategically and/ or for economic gain by institutions and governments. Less attention has been given to the negative impact internationalization may have on students themselves, making De Moissac et al.'s contribution on mental health and help-seeking strategies of international students in Canada an important and timely new angle through which to study the ramifications of internationalization. As De Moissac et al. show in the context of North America, the topic of student mental health in higher education is both better understood and better supported than in the past, making it an issue that is unlikely to abate. Instead, continued efforts to destigmatize mental health and students' and institutions' growing awareness of the importance of prioritizing good mental health suggest the further embedding of mental health research as part of higher education studies.

De Moissac et al.'s study of international students at two Manitoban universities seeks to address gaps in our understanding of how international students view their health and well-being and the factors that come into play when help for mental health issues is sought. The choice to focus on a French language and an English language university enables the article to explore how the different populations of international students on these campuses deal with mental health challenges. The authors' finding that the international students surveyed "exhibit stronger overall mental health and psychological characteristics than domestic students" (p. 66) is intriguing given the potential challenges that the article thoughtfully discusses. The article's efforts to diversify the study of internation- al students' mental health both linguistically and also by looking beyond the top three sending countries of international students to Canada (China, India, and France) sets the tone for future studies that bring together mental health, internationalization, and intersections of identity.

Continuing discussions touched on in other articles of international students and their status and belonging, Malette and Ismailzai's article examines in more detail how exclusion plays out on the campus of a large public university in western Canada. The study draws on 150 interviews undertaken between 2006 and 2018 with undergraduate students identifying as international and Asian, domestic and white, and domestic and Asian, to examine their on-campus engagement in social activities. More than simply describing what they do, the article aims to interrogate how these groups understand each other, and from there to think about how bridges between groups could be built and sustained. Both the empirical and analytical elements of this study do much to advance and refine our understanding of the ways that students engage with each other and on campus and will be particularly relevant for support staff in higher education institutions.

Counter to stereotypical perceptions that Asian international students do not get involved in campus activities, Malette and Ismailzai find a high level of participation in on-campus ethnicity-based clubs that is also higher than the domestic groups surveyed. Despite being subject to racist critiques of their very presence in Canada, Asian international students demonstrated willingness to build relationships with others on campus to reduce the distance some experienced with their $\mathrm{Ca}$ nadian peers. Nevertheless, the qualitative findings also establish that the stereotype of self-exclusion by Asian international students is perpetuated by white domestic students. These white students express what is essentially a fear of a group they do not understand and are not part of, retaining barriers between them and continuing the same form of exclusionary talk seen at the parliamentary level in McCartney's article.

\section{Shaping Sustainable Futures for Higher Education Internationalization}

The new agenda put forward in these articles is not designed to be a comprehensive program for future 
research, policy, and practice. Other key issues for the sustainability of internationalization, such as the impact of climate change on international mobility and research and the unresolved tensions between Indigenization and internationalization, await additional coverage in future research. Rather, the strength of this collection is in singling out areas of interest that have risen to prominence in recent years or are recurring issues of importance to higher education internationalization in Canada. Two factors stand out from this collection. The first relates to internationalization discourse and the way this is represented and analysed theoretically and methodologically. The second is the emphasis on one particular set of actors: international students.

As becomes apparent from the articles in this special issue, discourse is key, both as presented by one set of actors (e.g., universities, MPs) and in conversation between actors (e.g., those involved in the policy arena). Our understanding of internationalization is enhanced by analysing how actors talk about themselves and by understanding the processes by which results (strategies, policies, etc.) are reached. In the articles, the use of lenses such as discursive institutionalism, critical discourse analysis, and discourse coalition framework prove very effective in this regard. The prevalence, although not exclusive use, of qualitative methods across the articles accentuates the roles played by various actors in internationalization and the importance of understanding and analysing their experiences. The choice to focus on discourse adds important theoretical grounding to studies of internationalization, for example demonstrating direct connections between Canada's colonial heritage and how this continues to shape internationalization.

Secondly, as is evident from the depth of coverage in the articles, international students are pivotal to how internationalization is understood and operationalized. Whether as desired objects to fulfill institutional internationalization strategies or as agents shaping their on-campus experiences, the role of international students continues to be highly significant. At the nexus of federal policy on immigration, provincial policy governing funding, and institutional policies, as well as being actors in their own right, it is perhaps unsurprising to see international students so high on the agenda. The Covid-19 pandemic, which has already had a severe short-term impact on higher education internationaliza- tion, will reinforce the centrality of international students to studies of internationalization in the future.

International student mobility has been very adversely affected as a result of Covid-19: the previous concept of "internationalization at home" has come to take on a very literal meaning with borders closed and international travel grinding to a near halt (Marinoni et al., 2020; Xiong et al., 2020). Whereas the articles in this collection were written before the onset of the pandemic, connections between their themes and emerging issues abound. For instance, early research has found that "international students are facing more impediments to maintaining their mental health under the Covid-19 pandemic and beyond" (Chen et al., 2020, p. 1) than domestic students. The Canadian policy framework for internationalization has also shifted as a result of Covid-19. A study of initial responses by higher education institutions and the country's multilevel governance structures noted a creeping federalism in Ottawa's actions even though the constitutional responsibility for higher education remains with the provinces (El Masri \& Sabzalieva, 2020). The pandemic has also changed the way that research is taking place across borders, leading to more cooperation and more research on the emerging issues related to Covid-19 (Lee \& Haupt, 2020).

The effects of Covid-19 are still unfolding as this special issue goes to press and for now it will have to suffice to note the importance of continuing to interrogate the challenges already identified in higher education internationalization in light of the effects of the pandemic, as well as to establish the gaps that emerge from a post-pandemic terrain that has not yet been attained.

Back in 2004, Knight asked:

...what, in the year 2020 , will be seen as the major accomplishments of internationalization during the past 30 years?... What are key issues or questions that require further evaluation, research, and policy analysis to address and guide the long-term impact and implications of internationalization at both the institutional and sector levels? (Knight, 2004, pp. 29-30)

The articles in this special issue and the SSFIHE conference that preceded it are a Canadian-oriented contribution towards addressing these important questions.

An important discovery from across the articles is the way they highlight significant continuities and convergence in Canadian higher education internationaliza- 
tion. The major accomplishments Knight asks about can be answered in the singular through the overwhelming emphasis on international students. The economic rationale for their continued recruitment and-even if to varying extents based on political shifts-retention has dominated policy and practice and been a major cause of critique by researchers. Although this continuity is also significant to the focus of several of the articles in this issue, the collective contribution is not limited to demonstrating the long-term attention paid to international students. That in itself is an important outcome and the articles do successfully bring out aspects of the international student story that have not yet been told and do so by paying attention to the specificities of the Canadian higher education context.

Beyond this, however, the significance of the special issue also lies in the way that the articles each bring a new way of examining and framing higher education internationalization, adding much needed theoretical and analytical perspectives to the field. Thus, while many of the key issues in higher education internationalization remained the same in 2020 as they were in 2004, it is the questions we ask about them that are changing. It is in the process of opening up the field to these new questions that the opportunities to truly shift the internationalization agenda will arise.

\section{Acknowledgements}

The exceptional dedication and excellent contributions of all the members of the SSFIHE 2019 committee not only ensured that the entirely student-run conference was a success but laid the foundations for this special issue to proceed. Very special thanks to Scott Clerk, Nadiia Kachynska, Clara Kim, and Diane Simpson.

\section{References}

Altbach, P. G., \& de Wit, H. (2018). Are we facing a fundamental challenge to higher education internationalization? International Higher Education, 93, 2-4. https://doi.org/10.6017/ihe.0.93.10414

Beck, K. (2013). Making sense of internationalization: A critical analysis. In Y. Hébert \& A. Abdi (Eds.), Critical perspectives on international education (pp. 43-59). Brill Sense.
Buckner, E., Clerk, S., Marroquin, A., \& Zhang, Y. (2020). Strategic benefits, symbolic commitments: How Canadian colleges and universities frame internationalization. Canadian Journal of Higher Education, 50(4), 20-36. https://doi.org/10.47678/cjhe. vi0.188827

Canadian Bureau for International Education. (2018). International students in Canada (No. 10; CBIE Research in Brief). Canadian Bureau for International Education. https://cbie.ca/wp-content/ uploads/2018/09/International-Students-in-Canada-ENG.pdf

Chen, J. H., Li, Y., Wu, A. M. S., \& Tong, K. K. (2020). The overlooked minority: Mental health of international students worldwide under the COVID-19 pandemic and beyond. Asian Journal of Psychiatry, 54, 102333. https://doi.org/10.1016/j.ajp.2020.102333

De Moissac, D., Graham, J. M., Prada, K., Gueye, N. R., \& Rocque, R. (2020). Mental health status and help-seeking strategies of Canadian international students. Canadian Journal of Higher Education, 50(4), 52-71. https://doi.org/10.47678/cjhe. vi0.188815

El Masri, A. (2020). International education policymaking: A case study of Ontario's Trillium Scholarship Program. Canadian Journal of Higher Education, 50(4), 1-19. https://doi.org/10.47678/cjhe. vi0.188819

El Masri, A., \& Sabzalieva, E. (2020). Dealing with disruption, rethinking recovery: Policy responses to the COVID-19 pandemic in higher education. Policy Design and Practice, 3(3), 312-333. https://doi.org/1 $\underline{0.1080 / 25741292.2020 .1813359}$

Global Affairs Canada. (2014). Canada's international education strategy (2014-2019). https://www.international.gc.ca/education/report-rapport/strategy-strategie-2014/index.aspx?lang=eng

Global Affairs Canada. (2017). Economic impact of international education in Canada - 2017 update. https:ll www.international.gc.ca/education/report-rapport/ impact-2017/sec-1.aspx?lang=eng

Global Affairs Canada. (2019). Evaluation of Canada's international education strategy. https://www. 
international.gc.ca/gac-amc/publications/evaluation/2019/evaluation-education.aspx?lang=eng

Government of Canada. (2019). Building on success: International education strategy (2019-2024). Global Affairs Canada. https://www.international.gc.ca/education/strategy-2019-2024-strategie.aspx?lang=eng

King, C. (2020). Discursive power and the internationalization of universities in British Columbia and Ontario. Canadian Journal of Higher Education, 50(4), 100-115.

Knight, J. (2003). Updated definition of internationalization. International Higher Education, 33, 2-3. https:/l doi.org/10.6017/ihe.2003.33.7391

Knight, J. (2004). Internationalization remodeled: Definition, approaches, and rationales. Journal of Studies in International Education, 8(1), 5-31. https://doi. org/10.1177/1028315303260832

Knight, J. (2014). Is internationalisation of higher education having an identity crisis? In A. Maldonado-Maldonado \& R. M. Bassett (Eds.), The forefront of international higher education: A festschrift in honor of Philip G. Altbach (pp. 75-87). Springer. https:/l doi.org/10.1007/978-94-007-7085-0 5

Knight, J., \& de Wit, H. (2018). Internationalization of higher education: Past and future. International Higher Education, 95, 2-4. https://doi.org/10.6017/ ihe.2018.95.10715

Lee, J. J., \& Haupt, J. P. (2020). Scientific globalism during a global crisis: Research collaboration and open access publications on COVID-19. Higher Education. https://doi.org/10.1007/s10734-02000589-0

Malette, N., \& Ismailzai, E. (2020). Building bridges to better bonds?: Differential on-campus participation between international and domestic students. $\mathrm{Ca}$ nadian Journal of Higher Education, 50(4), 72-86. https://doi.org/10.47678/cjhe.vi0.188817

Marinoni, G., van't Land, H., \& Jensen, T. (2020). The impact of Covid-19 on higher education around the world: IAU global survey report. International Association of Universities.

McCartney, D. M. (2020). Border imperialism and exclusion in Canadian Parliamentary talk about international students. Canadian Journal of Higher Education, 50(4), 37-51.

Mok, K. H. (2018). Does internationalisation of higher education still matter? Critical reflections on student learning, graduate employment and faculty development in Asia. Higher Education Quarterly, 72(3), 183-193. https://doi.org/10.1111/hequ.12170

Paikin, S. (2019, May 8). Why depending on international students is a double-edged sword for Ontario schools. TVO.Org. https://www.tvo.org/article/whydepending-on-international-students-is-a-doubleedged-sword-for-ontario-schools

Proctor, D., \& Rumbley, L. E. (Eds.). (2018). The future agenda for internationalization in higher education: Next generation insights into research, policy, and practice. Routledge. https://www.taylorfrancis.com/ books/e/9781315266909

Sá, C. M., \& Sabzalieva, E. (2018). The politics of the great brain race: Public policy and international student recruitment in Australia, Canada, England and the USA. Higher Education, 75(2), 231-253. https:/l doi.org/10.1007/s10734-017-0133-1

Schiedeck Soares de Souza, C. (2020). Brazilian federal institutes and Canadian colleges: Sharing experiences internationally. Canadian Journal of Higher Education, 50(4), 87-99.

Scott, C., Safdar, S., Desai Trilokekar, R., \& El Masri, A. (2015). International students as 'ideal immigrants' in Canada: A disconnect between policy makers' assumptions and the lived experiences of international students. Comparative and International Education/ Éducation Comparée et Internationale, 43(3), 5.

Shingler, B. (2019, November 5). Quebec foreign students hoping to settle in province feel "abandoned" by CAQ reforms. CBC News. https://www.cbc.ca/ news/canada/montreal/quebec-immigration-peq-legault-1.5348918

Stein, S., \& de Andreotti, V. O. (2016). Cash, competition, or charity: International students and the global imaginary. Higher Education, 72(2), 225-239. https://doi.org/10.1007/s10734-015-9949-8

Study Group on Global Education. (2017). Global 
education for Canadians - Centre for international policy studies. https://www.cips-cepi.ca/projects/ study-group-on-global-education/

Syed, F. (2019, June 7). Here's everything the Doug Ford government cut in its first year in office. National Observer. https://www.nationalobserver. com/2019/06/07/news/heres-everything-doug-fordgovernment-cut-its-first-year-office

Trilokekar, R. D., El Masri, A., \& El Masry, H. (2020). Power, politics, and education: Canadian universities and international education (IE) in an era of new geopolitics. Canadian Journal of Higher Education, 50(3), 79-95.

Universities Canada. (2017, November 15). Cana$d a$ 's global moment: Students from around the world choose Canada. https://www.univcan.cal media-room/media-releases/canadas-global-moment-students-around-world-choose-canadal

Xiong, W., Mok, K. H., Ke, G., \& Cheung, J. O. W. (2020). Impact of COVID-19 pandemic on international higher education and student mobility: Student perspectives from mainland China and Hong Kong. Centre for Global Higher Education. https:ll www.researchcghe.org/publications/working-paper/ impact-of-covid-19-pandemic-on-international-higher-education-and-student-mobility-student-perspectives-from-mainland-china-and-hong-kong/

Yerger, D., \& Choudhary, M. (2019). Is it a Trump bump, spike, or plateau? India's changing interest in Canadian versus U.S. universities. Journal of International Students, 9(4), 1196-1202.

\section{Contact Information}

Emma Sabzalieva

e.sabzalieva@unesco.org 